\title{
THE FEMALE COSTUME OF THE EAST GERMANIC TRADITION FEATURING BIG TWO-PLATE BROOCHES IN THE NORTH CAUCASUS IN THE GREAT MIGRATION PERIOD
}

\author{
A N N A M A S T Y K O A
}

\begin{abstract}
This paper addresses the female costume of the East Germanic tradition which was widespread in the North Caucasus throughout the Great Migration period. It was characterised by one or two big two-plate brooches (measuring more than $10 \mathrm{~cm}$ in length) worn on the chest or shoulders. Germanic elements, in female costume in particular, spread through the material culture of the North Caucasus in the early stage of the Great Migration period, in the last third of the $4^{\text {th }} \mathrm{c}$. and the first decades of the $5^{\text {th }} \mathrm{c}$. However, the costume featuring big two-plate brooches appeared in the said region, similarly to Europe in general, a bit later, in the second third of the $5^{\text {th }} \mathrm{c}$. Almost all the archaeologically documented cases of the costume in question appearing in the burial context were in the Black Sea coast of the North Caucasus, primarily in the cemetery of Diurso in the vicinity of the present-day Novorossiysk. The $6^{\text {th }} \mathrm{c}$. written sources documented there the area where the Tetraxitae Goths lived. According to Procopius of Caesarea, the Tetraxitae Goths originated from the eastern Crimea. The $6^{\text {th }} c$. Anonymous Periplus mentioned in the same area the Eudusiani people who spoke Gothic language. In the $5^{\text {th }}$ c., the Tetraxitae Goths migrated from the eastern Crimea to the North Caucasus: the Utigur Huns took them when leaving the northern Black Sea area for the east. Outside of the coastal area, the big two-plate brooches and their diminished copies occurred on the sites of the type Pashkovskii-Karpovka which belonged to the proto-Adyghe population of the Kuban. The costume featuring two-plate brooches was certainly considered prestigious at least by the Tetraxitae Goths who created the cemetery of Diurso. The graves containing the attire in question usually featured rather rich grave goods. All the researchers agree that the costume featuring big two-plate brooches on the chest or shoulders was of East Germanic origin. Its prototype existed in the Cherniakhov archaeologic culture. In the Hunnic period, the costume with small two-plate brooches, which were especially widespread in the Cherniakhov culture and the northern Black Sea areas, became the background for the shaping of the 'princely' costume with big brooches of similar form. In its own turn, this new prestigious costume became the prototype of the East Germanic attire with big two-plate brooches as a 'folk' replica of prestigious East Germanic costume of the Hunnic period. From the second half of the fifth to the early sixth century, this costume was imitated by the East Germanic 'middle class' to become widely distributed in the Barbaricum from the North Caucasus to the Pyrenees.
\end{abstract}

Keywords: North Caucasus, Great Migration Period, Tetraxitae Goths, female costume, brooches.

The female costume of the East Germanic tradition in the Great Migration period typically featured one or two brooches on shoulders or chest. Especially demonstrative are big brooches (measuring more than $10 \mathrm{~cm}$ in length) often made of a metal sheet with a semi-circular or polyhedral head-plate, a relatively short bow, and an elongated plated foot-plate (Fig. $1: 1-11) .{ }^{1}$ This paper will discuss the pattern of the appearance and distribution of this costume in the North Caucasus.

Germanic elements, in the female costume in particular, spread through the material culture of the North Caucasus already in the early stage of the Great Migration period, in the last third of the fourth and the first decades of the fifth centuries (for details see: Kazanski/Mastykova 2003a). However, the costume featuring big two-plate brooches appeared in this region, as everywhere in Europe, a little bit later, in the second third of the $5^{\text {th }} \mathrm{c}$. (Mastykova 2009, 51, 52). Almost all the archaeologically documented cases of the costume in question discovered in the burial context appeared in the Black Sea coast of the North Caucasus (Fig. 2: 1), in the vicinity of the present-day Novorossiysk, where the sixth-century written sources documented the area populated by the Tetraxitae Goths. According to Procopius of Caesarea, the Tetraxitae Goths originated from the eastern Crimea. There they joined the Utiguri Huns who retreated from Europe (according to Procopius, in the period when the Vandals already established themselves in

\footnotetext{
1 The Russian scholarship traditionally determined them as dvuplastinchatye fibuly, the German as Blechfibeln, and the French as fibules en tôle d'argent. The English language does not have a stable adequate equivalent of the said terms. This paper suggests the term two-plate brooches for the artefacts in question.
} 

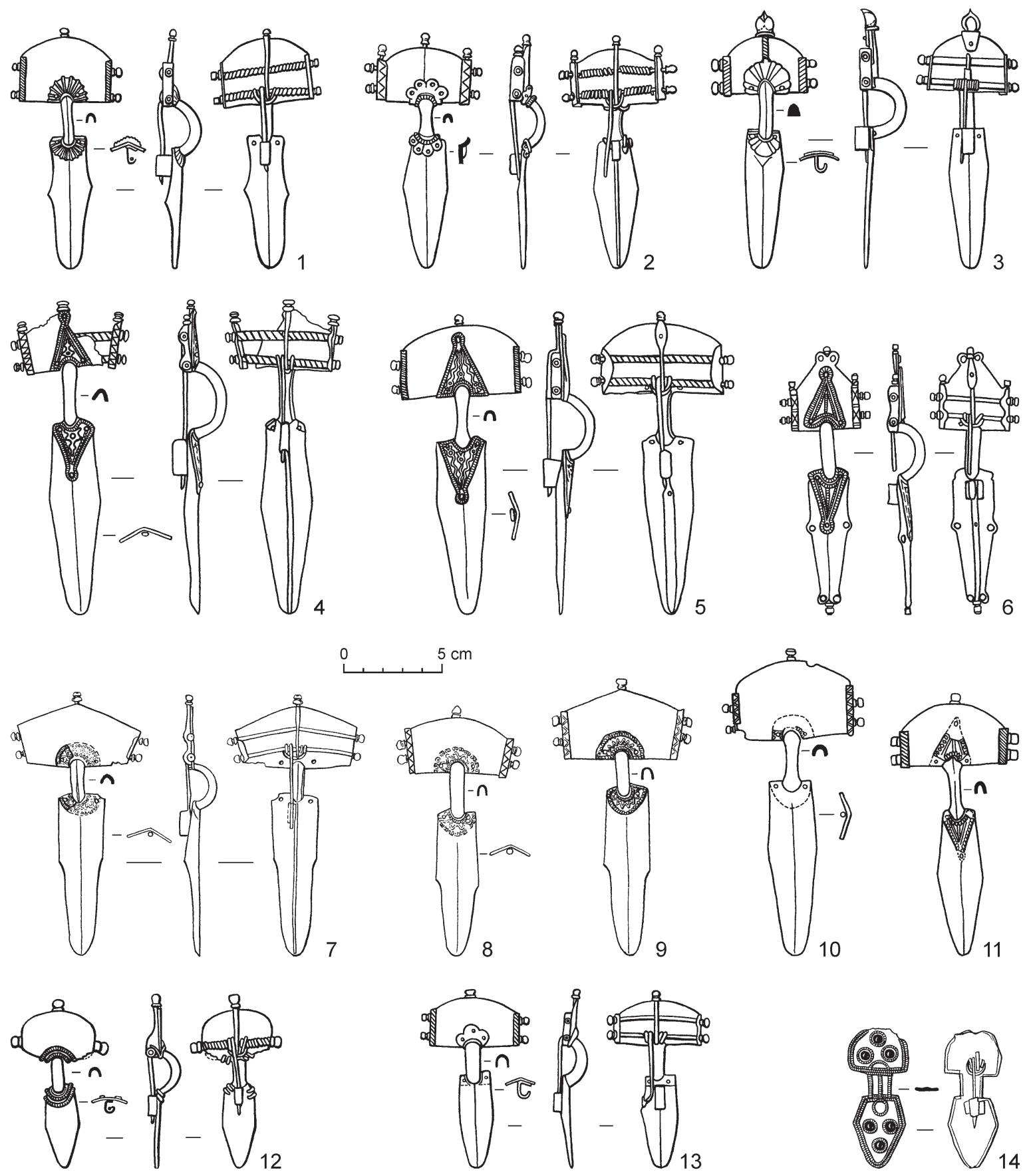

Fig. 1. Diurso, Krasnodar distr. The examples of two-plate brooches from the post-Hunnic period from cemetery. 1, 12 - grave 483; 2, 3 - grave 300; 4 - grave 197; 5 - grave 292; 6 - grave $420 ; 7$ - grave 259; 8 - grave 408; 9 - grave 410; 10 - grave 291; 11 - grave 500; 13 - grave 510; 14 - grave 490 (Dmitriev 1982, fig. 1).

North Africa, i.e. after 429 AD) and migrated with them to the North Caucasus (Procopius 1962-1968, VIII: 5). In 548 AD the embassy from the Tetraxitae came to Constantinople (Procopius 1962-1968, VIII: 4: 11-13). It was a rather numerous people, as in $551 \mathrm{AD}$ a troop of the Tetraxitae of 2,000 warriors, a considerable force in that period, participated in the war between the Utiguri and the Cutriguri Huns (Procopius 1962-1968, VIII: 18, 22). Another source mentioning the Goths in the Caucasus coast is the anonymous Periplus, possibly dated to the $6^{\text {th }}$ c., the so-called Pseudo-Arrian, which mentioned the people of Eudusiani, who spoke Gothic or Taurian language and lived near the 


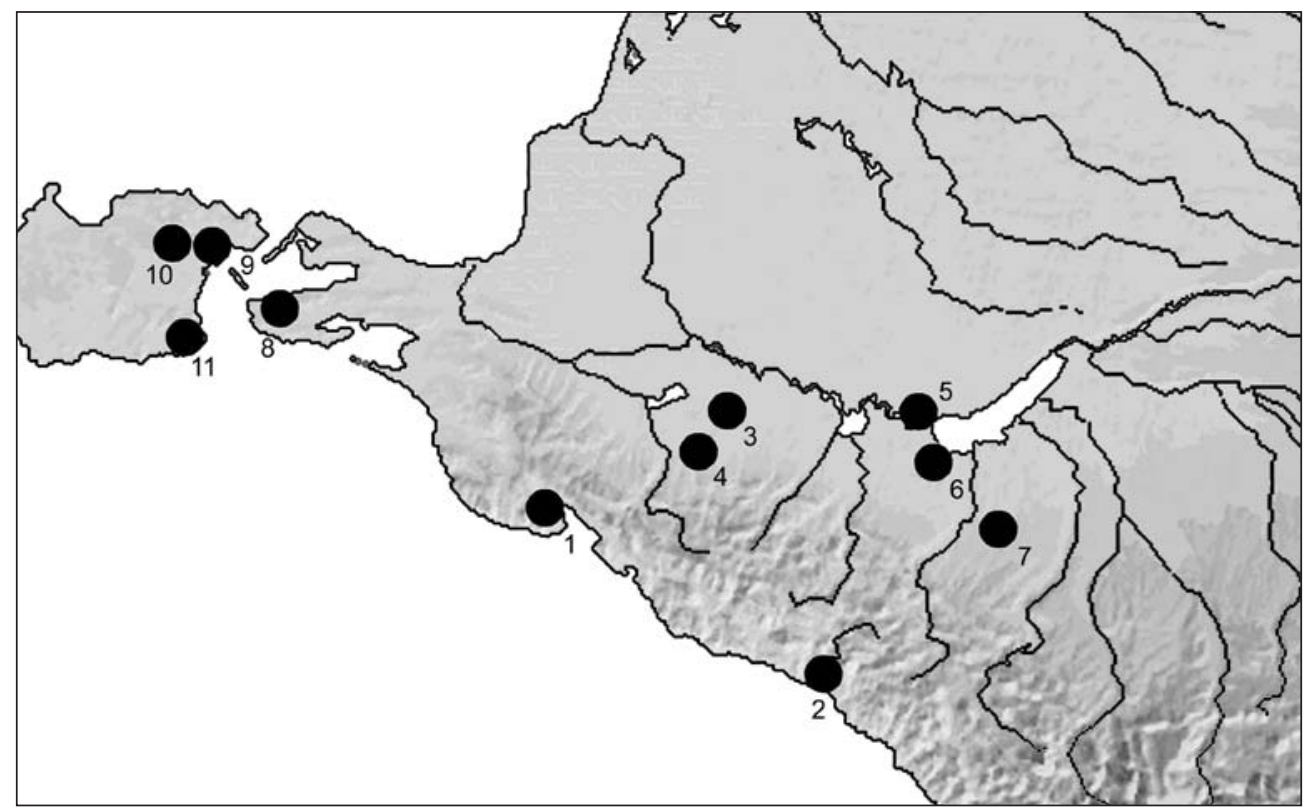

Fig. 2. Distribution area of the two-plate brooches featuring the East Germanic tradition in the post-Hunnic period in the north-eastern Black Sea area. 1 - Diurso; 2 - Bzhid I; 3 - Khabl'; 4 - Varnavinskoe, site 3; 5 - Khutor Lenina, site 4; 6 - Krasnodarskoe Lake; 7 - Maikop; 8 - Taman'; 9 - Kerch'; 10 - Chokrak; 11 - Dzhurga-Oba. Due to the size of the map, the location of archaeological sites is tentative.

harbour of Pagras² (Continuation of the Anonymous Periplous, Codex Londonienses, § 22. Cited through: Baschmakoff 1948, 139).

Present-day researchers related the archaeological sites of the Tetraxitai Goths in the Black Sea coast of the Caucasus, in the vicinity of Novorossiysk, primarily to the cemetery of Diurso (Fig. 2: 1; Dmitriev 2003). Unfortunately, the cemetery of Diurso has not been published completely; however, the graves containing two-plate brooches have been introduced into the scholarship (Dmitriev 1982). There are but fragmentary data concerning other graves. The total number of graves from the fifth to ninth century investigated on the cemetery of Diurso is 525 plus 16 graves of horses. In the excavator A. V. Dmitriev's words, the graves published belonged to the early stages of the cemetery. According to our present knowledge, these stages date from the 450 s to $530 \mathrm{~s} / 540 \mathrm{~s} \mathrm{AD}$ (for details see: Kazanski 2002). Big two-plate brooches occurred in some female and children's graves no. 197, 259, 292,
$408,410,420,490,500,516,517$. There were smaller imitations of big two-plate brooches in graves 483 and 510 (Fig. 1: 12, 13). Moreover, two-plate brooches became offerings uncovered in male graves 300 and 291 (Fig. 1: 2, 3, 10). There is a big two-plate brooch originating from grave 57 in the cemetery of Bzhid I (Fig. 2: 2); another artefact was discovered as a chance find in Myskhako, but the latter stemmed rather from an earlier stage of the Hunnic period (Mastykova 2002; 2009, cat. no. 1: 1-3). Outside the coastal area, big two-plate brooches and their smaller copies occurred at the sites of the type Pashkovskii-Karpovka, which belonged to the proto-Adyg population of the Kuban, such as Khabl', grave 1; Khutor Lenina, site 4; Krasnodar Water Reservoir; Maikop; ${ }^{3}$ Varnavinskoe, site 3, grave 38 (Fig. 2: 3-7; Mastykova 2009, 51, 52; cat. no. 2: 1, 3, 4; Sukhanov/Sviridov 2018, fig. 3: 4). ${ }^{4}$

Paired two-plate brooches are documented at the dead person's shoulders (Fig. 3: 1-3; Diurso, graves 408, 410, 420; Khabl'). In grave 483 of the

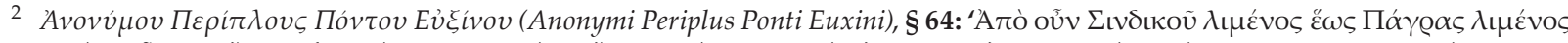

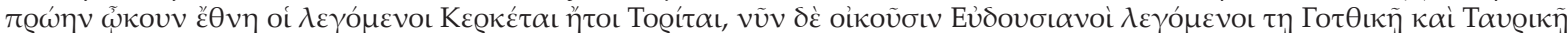
$\chi \varrho \omega \mu \varepsilon v o เ \quad \gamma \lambda \omega \tau \tau \eta$.' See A. Podossinov's translation: '<The space> from the Sindian harbour as far as the harbour of Pagras was earlier inhabited by the peoples called the Kerketai or the Toritai, but now here live so-called Eudousianoi who are using the Gothic and the Tauric language' (Podossinov 2011).

3 Most likely, this is the place where the artefact was purchased.

4 Moreover, the sites in the western and central Sub-Caucasia contained local replicas and imitations of two-plate brooches, which will not be considered in this paper (see: Mastykova 2009, 53-55).
} 


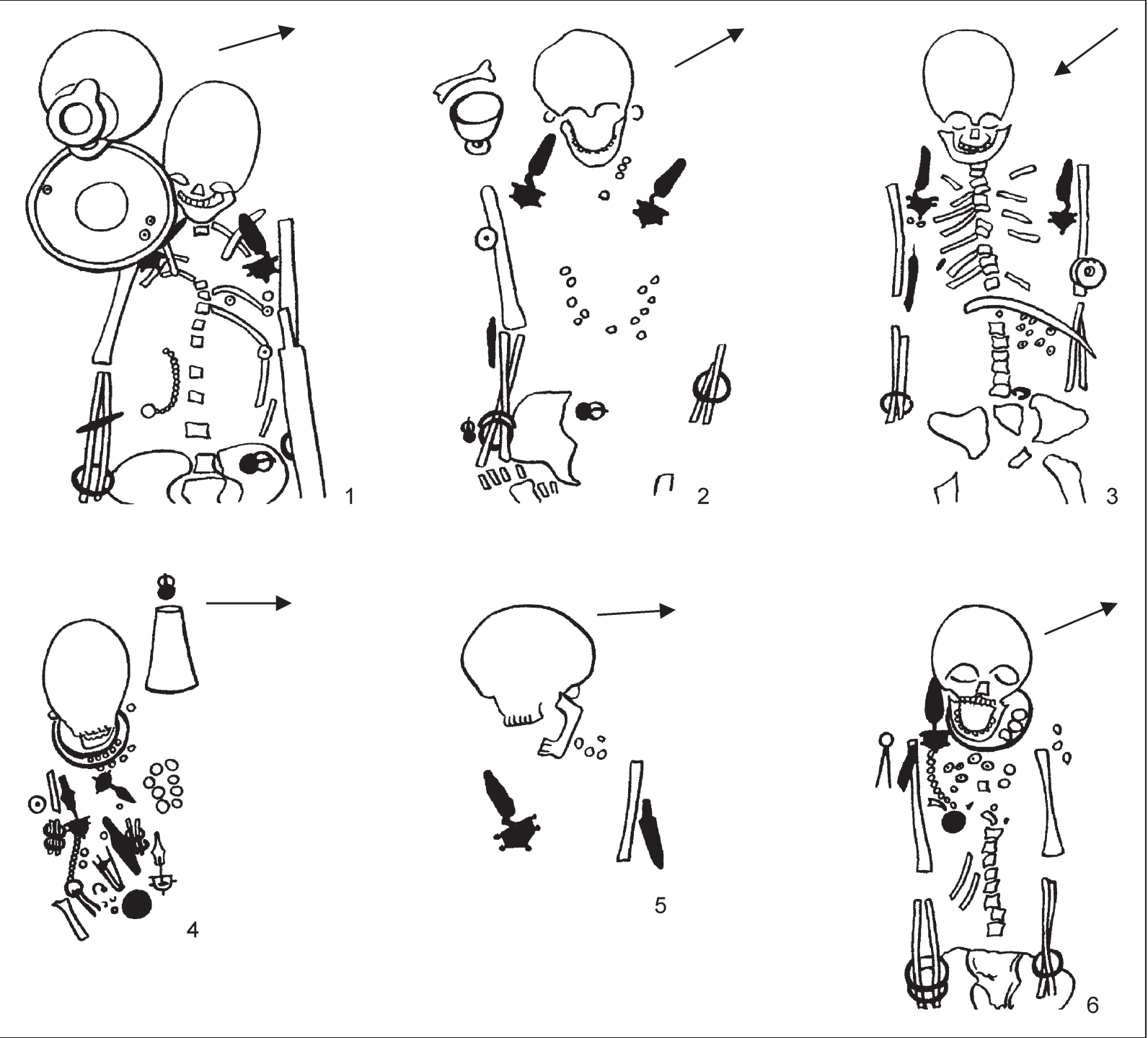

Fig. 3. Diurso, Krasnodar distr. Location of two-plate brooches in the graves of cemetery. 1 - grave 408; 2 - grave 410; 3 - grave 420; 4 - grave 483; 5 - grave 517; 6 - grave 516 (Dmitriev 1982, fig. 7: 1-6).

cemetery of Diurso there were three two-plate brooches: two of them laid on the shoulders and the third one across the chest, closer to the neck area (Fig. 3: 4). There were solitary two-plate brooches located on the left shoulder (Diurso, grave 490) or on the right shoulder (Fig. 3: 5, 6; Diurso, graves 292, 500, 516, 517; Bzhid I, grave 57; Mastykova 2009, 147).

Undoubtedly, the costume featuring two-plate brooches was considered prestigious by at least the Tetraxitai Goths who created the cemetery of Diurso (for details see: Mastykova 2002). The graves containing the costume in question were accompanied with rather abundant grave goods. The attire featuring two-plate brooches contained additional bow brooches (Bzhid I, grave 57; Diurso, graves 410 and possibly 517), neck-rings (Diurso, graves 292, 483, 500, 516), bracelets (Diurso, graves 292, 408, 410, 420, 483, 490, 500, 516; Bzhid I, grave 57), necklaces of beads (Diurso, graves 292, 408, 410, 483, 490, 516, 517; Khabl'); various earrings (Diurso, graves 292, 410, 483, 490, 517; Bzhid I, grave 57), belt fittings (Diurso, graves 408, 410, 420, 500, 517), footwear fittings (Diurso, graves 408, 410, 483, 490, 500, 516, 517; Khabl'), pectoral chains (Diurso, graves 408, 410, 483, 516; Bzhid I, graves 57), a chain with a beast-nail-shaped pendant (Diurso, graves 516); pendant beads (Diurso, graves 420, 500; Mastykova 2009, 148, 149).

It would be hard to determine the function of the goods discovered on chest, near wrists, on girdle, or at/above the foot of the dead persons: were they the elements of the costume or funerary offerings? Among these finds, there were: accumulations of 
beads (Diurso, grave 420 - at the girdle; Diurso, grave 483 - in the chest and belly area, and also at the left humeral bone; Bzhid I, grave 57 - on the chest), mirrors (Diurso, grave 483 - on the girdle; Diurso, grave 410 - at the right humeral bone, accompanied with a chain and bow-shaped brooch fragments), knives (Diurso, grave 408 - across the right forearm, near a chain; Diurso, grave 410 - at the right elbow; Diurso, grave 420 - along the right humeral bones; Diurso, grave 483 - on the chest; Diurso, grave 516 - at the right shoulder, along with a toilet ware set; Diurso, grave 517 - at the left humeral bone, near bow-shaped brooch fragments), a pincers and a bone needle (Diurso, grave 500 - on the left leg), a needle-case and a toilet ware set hanged on chains (Diurso, grave 483 - on the chest), and a metal bulla (Diurso, grave 420 - on the left elbow). A possible explanation of such locations of grave goods is that they were hanged on chains or in some other way to the brooches or the belt. However, it is still possible that they were simply placed above the dead body as funeral offerings. The following artefacts probably became offerings: knives (Diurso, grave 408 - at the dead person's feet), earrings (Diurso, grave 483 - at the dead woman's belly), buckles (Diurso, grave 483 - near the glass vessel; Diurso, grave 410 - at the right wrist; possibly Diurso, grave 408 - at the foot near the footwear buckles, and grave 500 - at the right feet below the pitcher), a bow brooch (Diurso, grave 483 - in a fine pot near the dead person's foot), and a mirror (possibly Diurso, grave 500 - on the left shoulder). Obviously, there was a funeral offering comprising a set of artefacts placed at the dead person's feet: a pair of two-plate brooches, a pair of polyhedral earrings, a fragmented mirror, beads, and a knife (Diurso, grave 500; Mastykova 2009, 149).

All the researchers have interpreted the costume featuring big two-plate brooches on the chest or shoulders as of the East Germanic origin. Its prototype existed in the Cherniakhov culture. The female costume of the Cherniakhov population included a pair of small two-plate brooches (measuring less than $10 \mathrm{~cm}$ in length) and a necklace of beads, often (but not always) accompanied with a belt buckle, with a comb and/or a set of toilet ware hanged from the belt. This costume also included shell and pyramidal bone pendants (Mastykova 2007, with bibliography). Outside the Cherniakhov culture area, the graves containing paired small and medium-size two-plate brooches of the East Germanic tradition were widely distributed in Europe in the Great Migration period, from the South Urals to the Pyrenees (for details on them see: Ambroz 1966, 76-91; Gauß 2009). The costume featuring small two-plate brooches, especially distributed in the Cherniakhov culture and in the northern Black Sea areas, formed the background for the shaping of the 'princely' costume with big brooches of a similar form. The latter attire appeared in the Danube area ca. 400 AD (Stage D2, according to the European Barbaricum timeline, i.e. $380 \mathrm{~s} / 400 \mathrm{~s}-440 \mathrm{~s} / 450 \mathrm{~s}$ AD) in the aristocratic environment, and thence spread as far as the Pyrenees and the Caucasus (Ambroz 1966, 86-91; Kazanski/Mastykova 2003b; Kazanski/Périn 1997). The component parts of this 'princely costume' determined as the style/horizon Untersiebenbrunn were borrowed from different traditions: Germanic, Sarmatian-Alanic or, mor exactly, Pontic, which was widely represented among the nomads of the steppe, and also among the settled populations of the northern Black Sea area, and finally the Roman one (Kazanski 1996b; Kazanski/Mastykova 2003b). As an example, paired two-plate brooches in the costume of the type Untersiebenbrunn were borrowed from the Cherniakhov culture female costume (Bierbrauer 1971; Kazanski 1996b, 113-117), though mirrors and fine gold appliques represent steppe, or Sarmatian-Alanic influences (Mastykova 2014; Mastykova/Kazanski 2006). However, the latter are well known also among the settled populations of Bosporus and Tanais, and to a lesser degree, in the south-western Crimea. Big belt buckles were possibly borrowed from the prestigious Romanized costume of the fourth and fifth century (Martin 1991, 34-42, 55, 56, 63-79).

The horizon Untersiebenbrunn contains demonstrative big two-plate brooches plated with gold leaf and featuring polychrome decoration and plain silver two-plate brooches (for the numerous examples see: Tejral 2011). By the mid-fifth century (Stage D2/D3 or the horizon Smolín, corresponding to the $430 \mathrm{~s} / 440 \mathrm{~s}-460 \mathrm{~s} / 470 \mathrm{~s} \mathrm{AD})$, the aristocratic costume of the East Germanic tradition had predominating plain silver brooches, which were direct predecessors of the North Caucasus twoplate brooches (for the examples see: Tejral 2011). Their direct prototypes were probably the Danube brooches from Smolín with palmette-shaped appliques at the bow (cf. Fig. 1: 1-3), from Kosino with triangular appliques (cf. Fig. 1: 4-6, 11), and from Bakódpuszta with semi-circular appliques (cf. Fig. 1: 7-10; Mastykova 2009, 51, 52).

The North Caucasus brooches certainly were a simplified replica of the Danube brooch under study; most likely, these imitations were made in a workshop at the Cimmerian Bosporus (Mastykova 2009, 51), quite logical for the fashion trends of the period. Simultaneously, by the late fifth century, big two-plate brooches among the Germans in the 
Balkans and on the Danube and the Ostrogoths in Italy were replaced with the radiate-headed brooches, which had come into fashion from the mid-fifth century on. In the same period in the second half of the $5^{\text {th }} c$., there shaped a 'democratic' or 'less-expensive' version of the fashion for the formerly prestigious costume of the Danubian 'princesses' featuring two-plate brooches, which was represented by numerous finds from the Cimmerian Bosporus, particularly Kerch, Taman, Chokrak, and the vicinity of Kerch (Fig. 2: 8-10; for example: Ajbabin 2011, fig. 40: 6, pl. 28: 18, 21; 29: 2, 12, 25; Kühn 1974, pl. 230: 51: 30, 35; 231: 51: 39, 40; 224: 51: 93, 100, 102; Werner 1961, pl. 22: 99; 23: 101), as well as in more prestigious context of Dzhurga-Oba (Fig. 2: 11; Ermolin 2012, fig. 3: 9, 10), among the Goths of the country of Dory in the south-western Crimea (Ajbabin 2011, pl. 28: 18, 21; 29: 2, 12, 25; Kühn 1974, pl. 219: 51: 1, 6, 7; Werner 1961, pl. 22: 98), and in other regions of Europe among the Spanish Visigoths (Ebel-Zepezauer 2000, 16-21; Kazanski/López Quiroga/Périn 2018) and the persons of the East Germanic origin in Northern Gallia (for the details see: Kazanski/Mastykova/Périn 2008). Almost in every place, similarly to the cemetery of Diurso (Mastykova 2002), this type of costume now corresponded to the 'working class' of the barbarian society rather than the ruling elite culture. In this connection demonstrative are the finds in the eastern Crimea, in the neighbourhood of the North Caucasus. Although two-plate brooches remained also a part of the prestigious attire in this region according to the finds from the second half of the fifth century in the cemetery of Dzhurga-Oba, they also occurred in the urban cemeteries of Bosporus (present-day city of Kerch) withing the grave goods of the family tombs of the local 'middle class' (Ajbabin 2011, pl. 26: 5; 28: 18, 21; 29: 2, 12, 25). Specific distribution patterns of the fashion for two-plate brooches were most likely related with migrations of some prestigious groups of the middle Danube population. This fashion was possibly brought to Spain and Southern Gallia by the people of a noble member of the Amali family, Vidimer by name, who came to the Visigothic court, followed by his retinue, in 473 AD (Périn 1993). In northern Gallia, two-plate brooches possibly spread among the families of Danubian origin who joined the Late Roman/Early Merovingian army (for details see: Kazanski/Périn 1997). Finally, this fashion could be introduced into the northern Black Sea area by the German allies of the Huns, such as the Angisciri, who retreated to the east with Attila's sons after the defeat at Nedao (Kazanski 1996a, 327).
In the North Caucasus, one can see the beginning of the acculturation of the costume featuring big two-plate brooches introduced there by the Tetraxitai Goths: it was often accompanied with neck-rings (Diurso, graves 292, 483, 500, 516) uncommon for the Germans; moreover, paired brooches, which predominated in the Danube costume, appeared there only in four of eight cases (Diurso, graves $408,410,420,483)$. The absence of big belt buckles in the graves of the cemetery of Diurso should be particularly mentioned: these buckles, common in the East Germanic female's attire in the said period, are sometimes considered typical for it. Anyway, this interpretation requires considerable corrections. As it has already been mentioned, M. Martin proved that big belt buckles were typical of the prestigious Romanized female costume in the fifth and sixth century. However, Roman ladies wore these belts in their costume without brooches. The fifth-century Roman costume became the background for the shaping of the female attire of the Romanized population of the Burgundy, Aquitania, and Northern Gallia in the late $6^{\text {th }}$ and $7^{\text {th }} \mathrm{c}$. which included big belt buckles sometimes accompanied with small brooches of the Roman tradition. This is enough to prove that the big belt buckles were not a clothing element typical of the East Germans only (Martin 1991).

Moreover, some of the graves in the North Caucasus (Diurso, grave 490: Fig. 1: 14; Chmi 1 in North Ossetia, grave 4/little girl's skeleton; Pashkovskaia cemetery no. 1 in the Kuban area, grave 4 of the year 1949) featuring small brooches uncovered the local evolution of Germanic prototypes of two-plate brooches. Although the brooches discovered there belong to the local types, in grave 4 (little girl's skeleton) of Alan cemetery of Chmi 1 the brooches were paired typically of the German tradition, and in grave 490 of Diurso cemetery their position on the shoulder strictly meets with the East Germanic tradition (Mastykova 2009, 151). The adaptation of the formerly prestigious Germanic costume with two-plate brooches is well known among the nonGermanic peoples in the $5^{\text {th }}$ and $6^{\text {th }} \mathrm{c}$. Two-plate brooches of local forms distributed among the Balts in East Prussia, Baltic Sea Finns in the modern Finland area, among the Finno-Hungarian population of the forest zone of the Oka and the Volga basins, and even in the southern Urals and the Aral Sea area at the Dzhetyasar archaeological culture. Obviously, in a few cases, like those of the finds in the Urals or the Central Asia where the Germanic presence was hardly possible, the appearance of the brooches in question indicated the fashion (Mastykova 2009, 151, 152). 


\section{BIBLIOGRAPHY}

Ajbabin 2011 - A. I. Ajbabin: Archäologie und Geschichte der Krim in byzantinischer Zeit. Monographien des Römisch-Germanischen Zentralmuseums 98. Mainz 2011.

Ambroz 1966 - A. K. Ambroz: Fibuly iuga evropeiskoi chasti SSSR. II v. do n. e. $-I V$ v. n. e. Arkheologija SSSR. Svod arkheologicheskikh istochnikov D1-30. Moskva 1966.

Baschmakoff 1948 - A. A. Baschmakoff: La synthèse des périples pontiques. Méthode de précision en paléo-ethnologie. Etudes d'ethnographie, de sociologie et d'ethnologie 3. Paris 1948.

Bierbrauer 1971 - V. Bierbrauer: Zu den Vorkommen ostgotischer Bügelfibeln in Raetia II. Bayerische Vorgeschichtsblatter 36, 1971, 131-165.

Dmitriev 1982 - A. V. Dmitriev: Rannesrednevekovye fibuly iz mogil'nika na r. Diurso. In: A. K. Ambroz/ I. Erdeli (eds.): Drevnosti epokhi Velikogo pereseleniia narodov V-VIII vekov. Moskva 1982, 69-107.

Dmitriev 2003 - A. V. Dmitriev: Mogil'nik Diurso - etalonnyi pamiatnik drevnostei V-IX vekov. In: T. I. Makarova/S. A. Pletneva (eds.): Krym, Severo-Vostochnoe Prichernomor'e i Zakavkaz'e v epokhu srednevekov'ia IV-XIII veka. Moskva 2003, 200-206.

Ebel-Zepezauer 2000 - W. Ebel-Zepezauer: Studien zur Archäologie der Westgoten vom 5.-7. Jh. n. Chr. Mainz 2000.

Ermolin 2012 - A. Ermolin: Džurga-Oba. A Cemetery of the Great Migration Period in the Cimmerian Bosporus. In: V. Ivanišević/M. Kazanski (eds.): The Pontic-Danubian Realm in the Period of the Great Migration. Paris 2012, 340-348.

Gauß 2009 - F. Gauß: Völkerwanderungzeitlichiche „Blechfibeln". Typologie, Chronologie, Interpretation. Ergänzungsbände zum Reallexikon der germanischen Altertumskunde 67. Berlin - New York 2009.

Kazanski 1996a-M. Kazanski: Les germains orientaux au Nord de la mer Noire pendant la seconde moitié du $\mathrm{V}^{\mathrm{e}} \mathrm{s}$. et au VI ${ }^{\mathrm{e}} \mathrm{s}$. Materialy po arkheologii, istorii i etnografii Tavrii 5, 1996, 324-337, 567-581.

Kazanski 1996b - M. Kazanski: Les tombes "princières" de l'horizon Untersiebenbrunn, le problème de l'identification ethnique. In: L'identité des populations archéologiques. Actes des XVI rencontres internationales d'archéologie et d'histoire d'Antibes. Sophia Antipolis 1996, 109-126.

Kazanski 2002 - M. Kazanski: Die Chronologie der Anfangsphase des Gräberfeldes von Djurso. In: J. Tejral (Hrsg.): Probleme der frühen Merowingerzeit im Mitteldonauraum. Spisy Archeologického ústavu AV ČR Brno 19. Brno 2002, 137-158.

Kazanski/López Quiroga/Périn 2018 - M. Kazanski/J. López Quiroga/P. Périn: Le costume féminin "princier" de tradition germanique orientale à l'Époque des Grandes Migrations en Espagne et en Gaule du sud et ses réiniscences dans le Royaume Hispano-Wisigothique. In: J. López Quiroga (ed.): In Tempore Sueborum. El tiempo de los Suevos en la Gallaecia (411-585). El primer reino medieval de Occidente. Volumen de estudios. Ourense 2018, 61-84.
Kazanski/Mastykova 2003a - M. Kazanski/A. Mastykova: Les éléments germaniques dans la civilisation de la population du Caucase du Nord à l'époque des grandes migrations. In: C. von Carnap-Bornheim (Hrsg.): Kontakt - Kooperation - Konflikt. Germanen und Sarmaten zwischen dem 1. und 4. Jahrhundert nach Christus. Neumünster 2003, 135-176.

Kazanski/Mastykova 2003b - M. Kazanski/A. Mastykova: Les origines du costume "princier" féminin des Barbares à l'époque des Grandes Migrations. In: F. Chausson/H. Ingelbert (eds.): Costume et société dans l'Antiquité et le haut Moyen Age. Paris 2003, 107-120.

Kazanski/Mastykova/Périn 2008 - M. Kazanski/A. Mastykova/P. Périn: Die Archäologie der Westgoten in Nordgallien. Zum Stand der Forschung. In: S. Brather (Hrsg.): Zwischen Spätantike und Mittelalter. Ergänzungsbände zum Reallexikon der germanischen Altertumskunde 57. Berlin - New York 2008, 149-192.

Kazanski/Périn 1997 - M. Kazanski/P. Périn: Les Barbares "orientaux" dans l'armée romaine en Gaule. Antiquités Nationales 29, 1997, 201-217.

Kühn 1974 - H. Kühn: Die germanischen Bugelfibeln der Völkerwanderungszeit. II. Teil. Die germanischen Bügelfibeln in Süddeutschland. 2 Bände. Graz 1974.

Martin 1991 - M. Martin: Zur frühmittelalterlichen Gürteltracht der Frau in der Burgundia, Francia und Aquitania. In: G. Donnay (ed.): L'Art des invasions en Hongrie et en Wallonie. Mariemont 1991, 31-84.

Mastykova 2002 - A. V. Mastykova: Soziale Hierarchie der Frauengräber der Nordkaukasischen Dürsonekropole im fünften bis sechstens Jahrhundert (anhand der Trachtmaterialien). In: J. Tejral (Hrsg): Probleme der frühen Merovingenzeit im Mitteldonauraum. Spisy Archeologického ústavu AV ČR Brno 19. Brno 2002, 225-236.

Mastykova 2007 - A. V. Mastykova: Le costume féminin de la civilisation de Černjahov avec des fibules en tôle métallique. In: J. Tejral (Hrsg.): Barbaren in Wandel. Beiträge zur Kultur- und Identitätsumbildung in der Völkerwanderngszeit. Spisy Archeologického ústavu AV ČR Brno 26. Brno 2007, 201-217.

Mastykova 2009 - A. V. Mastykova: Zhenskii kostium Tsentral'nogo i Zapadnogo Predkavkaz'ia v kontse IV-seredine VI v. n. e. Moskva 2009.

Mastykova 2014 - A. V. Mastykova: "Kniazheskii" kostium s zolotymi applikatsiiami v epokhu Velikogo pereseleniia narodov. Kratkie soobshcheniia Instituta arkheologii 232, 2014, 136-150; colour insert: XIII-XVII.

Mastykova/Kazanski 2006 - A. Mastykova/M. Kazanski: A propos des Alains en Occident à l'époque des Grandes migrations: le costume à appliques en or. In: J. López Quiroga/A. M. Martínez Tejera/J. Morín de Pablos (eds.): Gallia e Hispania en el contexto de la presencia 'germánica' (ss. V-VII). Balance y Perspectivas. Actas de la Mesa Redonda hispano-francesca celebrada en la Universidad Autónoma de Madrid (UAM) y Museo Arqueológico Regional de la Comunidad de Madrid. Oxford 2006, 289-306. 
Périn 1993 - P. Périn: L'armée de Vidimer et la question des dépôts funéraires chez les Wisigoths en Gaule et en Espagne (Ve-VI ${ }^{\mathrm{e}}$ siècles). In: F. Vallet/M. Kazanski (eds.): L'armée romaine et les barbares du III ${ }^{\mathrm{e}}$ au VII ${ }^{\mathrm{e}}$ siècle. Saint-Germain-en-Laye 1993, 411-424.

Podossinov 2011 - A. V. Podossinov: Anonymi Periplus Ponti Euxini (2037). In: H.-J. Gehrke/F. Maier (eds.): Die Fragmente der Griechischen Historiker. Part V. Brill 2011. DOI: http://dx.doi.org/10.1163/1873-5363_jcv_a2037

Procopius 1962-1968-Procopius: History of the Wars. Volumes V-VIII. Translated by H. W. Dewing. Loeb Clasical Library 217. London - Cambridge (Mass.) 1962-1968.
Sukhanov/Sviridov 2018 - E. V. Sukhanov/A. N. Sviridov: Novye rannesrednevekovye pogrebeniia s territorii Zapadnogo Predkavkaz'ia. Rossiiskaia arkheologiia 4, 2018, 114-129.

DOI: http://dx.doi.org/10.31857/S086960630003393-1

Tejral 2011 - J. Tejral: Einhemische und Fremde. Das norddanubische Gebiet zur Zeit der Völkerwanderung. Spisy Archeologického ústavu AV ČR Brno 33. Brno 2011.

Werner 1961 - J. Werner: Katalog der Sammlung Diergardt (Völkerwanderungszeitlicher Schmuck). Band 1. Die Fibeln. Berlin 1961.

Manuscript accepted 22. 9. 2021

Translated by Nikita Khrapunov

Dr. hab. Anna Mastykova

Institute of Archaeology of the Russian Academy of Sciences 19 Dmitrii Ul'ianov Str.

RU - 117292 Moscow

amastykova@mail.ru 